\title{
The early management of cattle (Bos taurus) in Neolithic central Anatolia
}

Benjamin S. Arbuckle ${ }^{1} \&$ Cheryl A. Makarewicz ${ }^{2}$

The authors use metrical, demographic and body part analyses of animal bone assemblages in Anatolia to demonstrate how cattle were incorporated into early Neolithic subsistence economies. Sheep and goats were domesticated in the eighth millennium $B C$, while aurochs, wild cattle, were long hunted. The earliest domesticated cattle are not noted until the mid-seventh millennium $B C$, and derive from imported stock domesticated elsewhere. In Anatolia, meanwhile, the aurochs remains large and wild and retains its charisma as a hunted quarry and a stud animal.

Keywords: Anatolia, Neolithic, faunal analysis, aurochs, cattle, LSI, survivorship, skeletal parts distribution

\section{Introduction}

The domestication of cattle in the Near East approximately 10000 years ago was an important innovation that helped transform the subsistence systems of agro-pastoral societies that, previously, had relied largely on herds of domestic sheep and goats. The addition of domestic cattle (Bos taurus) to the Neolithic subsistence complex, a process that was initiated a millennium after the first successful management of caprines, facilitated the development of new economic and social systems that took advantage of the large packages of animal products, including meat, blood, skin, and renewable milk and traction, offered by managed cattle herds.

The processes by which domestic taurine cattle were incorporated into Neolithic agropastoral subsistence economies in central Anatolia may be documented through various lines of zooarchaeological evidence, including biometric, demographic and skeletal part representation data. Through comparative analyses of these faunal data recovered from multiple Neolithic sites located in the region, in particular the archaeofaunas from Erbaba and Çatalhöyük (Figure 1, Table 1), we argue for a new date and process of domestication that includes the importation of cattle previously domesticated elsewhere.

\section{Cattle exploitation at Erbaba}

The Neolithic site of Erbaba provides a valuable source of data for addressing the nature of cattle exploitation in central Anatolia at a critical time in the expansion of cattle management throughout the Near East and beyond (e.g. Horwitz \& Ducos 2005; Zeder 2008). Although

1 Department of Anthropology, Forensic Science and Archaeology, Baylor University, One Bear Place 97173, Waco TX, 76798-7173, USA (Email: benjamin_arbuckle@baylor.edu)

2 Stanford Archaeology Center, Stanford University, 488 Escondido Mall, Stanford CA, 94305, USA

Received: 14 October 2008; Accepted: 27 November 2008; Revised: 21 January 2009

ANTIQUITY 83 (2009): 669-686 
Table 1. Approximate dates for central Anatolian Neolithic sites mentioned in the text (Cessford 2001; Thissen 2002; De Cupere \& Duru 2003).

\begin{tabular}{lc}
\hline Central Anatolian Neolithic sites & Approximate dates (cal BC) \\
\hline Aşıklı Höyük & $8400-7400$ \\
Musular & $7500-7000$ \\
Suberde & $7400-7000$ \\
Çatalhöyük pre-XII to I & $7400-6000$ \\
Erbaba Höyük & $6600-6100$ \\
Höyücek & $6400 / 6200-6000$ \\
\hline
\end{tabular}

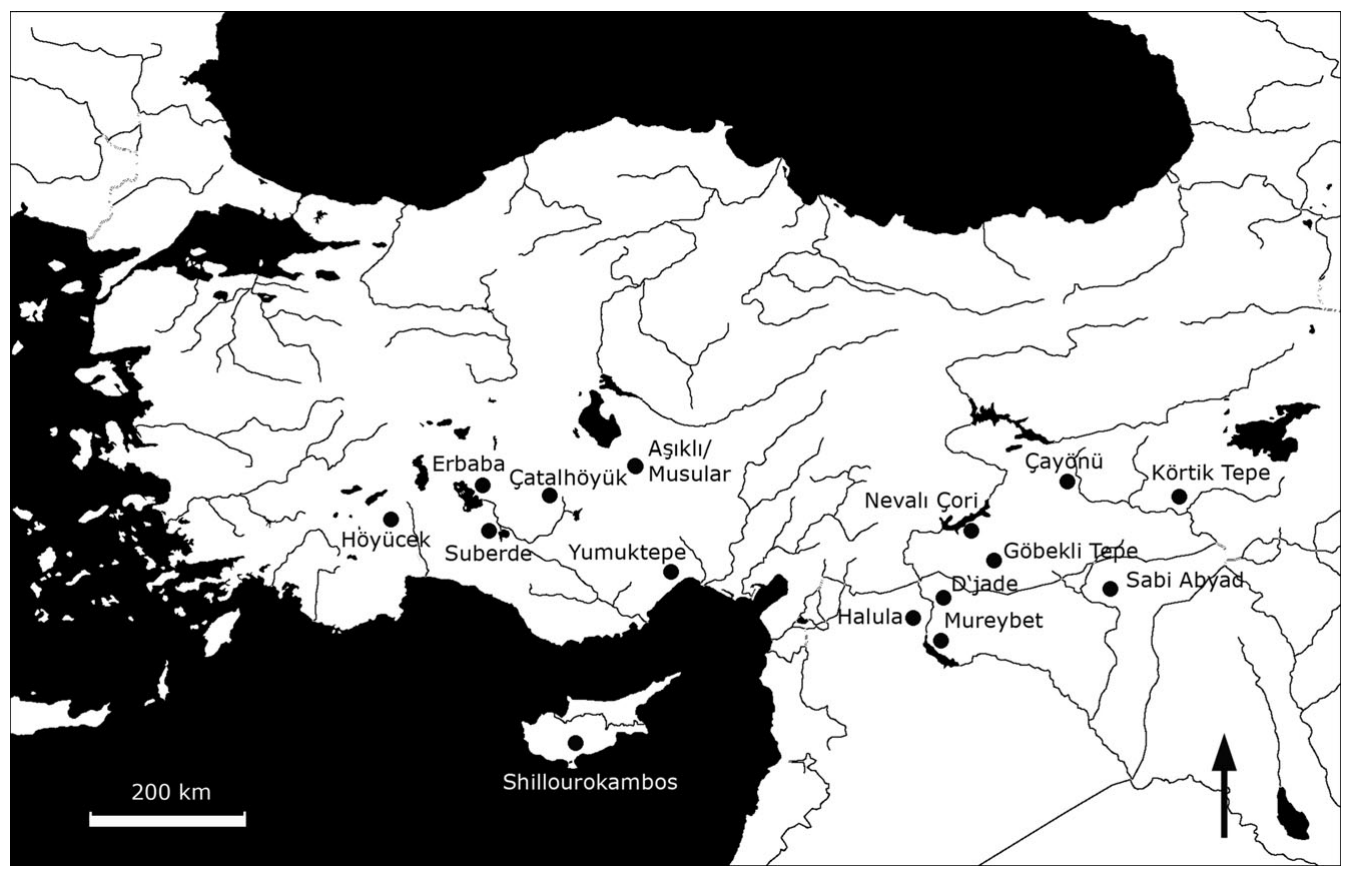

Figure 1. Map showing the location of sites mentioned in the text.

the site was excavated more than four decades ago, this important faunal assemblage has never been published in detail (although see Bordaz \& Alper-Bordaz 1976, 1979; Makarewicz 1999). Three major stratigraphic phases have been identified. Each layer dates to the Pottery Neolithic period and is roughly contemporary with the latest levels of Çatalhöyük (VI-I) (Bordaz \& Alper-Bordaz 1979). Radiocarbon dates obtained by Bordaz and Alper-Bordaz (1982) are problematic, with most determinations from wood charcoals yielding extremely large standard deviations, but recent efforts to re-date Erbaba on the basis of animal bone collagens have provided several dates confirming a Pottery Neolithic occupation of the site c. 6600-6100 cal BC (Table 2).

The animal economy at Erbaba was dominated by the herding of domestic caprines, although this was supplemented through the hunting of wild sheep and goats, as well as other wild ungulate taxa (Arbuckle 2006, 2008). Cattle are the third most abundant 
Table 2. Radiocarbon dates from Erbaba. Dates on charcoal are from Bordaz and Alper-Bordaz (1982).

\begin{tabular}{llllccc}
\hline Sample \# & Context & Material & ${ }^{14}$ C Date bp & $\begin{array}{c}\text { Calibrated } \\
\text { years BC }\end{array}$ & $\begin{array}{c}\text { 1 Sigma range } \\
\text { cal BC }\end{array}$ & $\begin{array}{c}\text { 2 Sigma range } \\
\text { cal BC }\end{array}$ \\
\hline AA66738 & level III & bone collagen & $7275 \pm 42$ & $6143 \pm 49$ & $6211-6079$ & $6226-6059$ \\
AA66739 & level III & bone collagen & $7504 \pm 85$ & $6354 \pm 83$ & $6441-6257$ & $6560-6118$ \\
AA66741 & level I & bone collagen & $7677 \pm 86$ & $6533 \pm 79$ & $6596-6453$ & $6686-6392$ \\
GX-2545 & level III & charcoal & $7530 \pm 430$ & $6518 \pm 478$ & $7025-5998$ & $7485-5661$ \\
GX-2544 & level III & charcoal & $6925 \pm 550$ & $5906 \pm 595$ & $6432-5318$ & $7170-4715$ \\
I-5151 & level III & charcoal & $7730 \pm 120$ & $6615 \pm 151$ & $6687-6444$ & $7029-6389$ \\
GX-2543 & level II-I & charcoal & $7550 \pm 570$ & $6606 \pm 642$ & $7140-5850$ & $7962-5383$ \\
\hline
\end{tabular}

Table 3. Relative frequency of mammalian taxa at Erbaba based on specimen counts. 'Other' includes carnivores, hare and rodents.

\begin{tabular}{|c|c|c|c|c|c|c|c|c|}
\hline & \multicolumn{2}{|c|}{ I } & \multicolumn{2}{|c|}{ II } & \multicolumn{2}{|c|}{ III } & \multicolumn{2}{|c|}{ All levels } \\
\hline & $\mathrm{N}$ & $\%$ & $\mathrm{~N}$ & $\%$ & $\mathrm{~N}$ & $\%$ & $\mathrm{~N}$ & $\%$ \\
\hline caprines & 1606 & 73.3 & 261 & 71.7 & 717 & 83.9 & 3012 & 76.8 \\
\hline cattle & 122 & 5.6 & 32 & 8.9 & 34 & 4.0 & 216 & 5.5 \\
\hline pig & 232 & 10.6 & 35 & 9.6 & 44 & 5.1 & 347 & 8.8 \\
\hline red deer & 82 & 3.7 & 15 & 4.1 & 23 & 2.7 & 126 & 3.2 \\
\hline fallow and roe deer & 58 & 2.7 & 12 & 3.3 & 9 & 1.1 & 83 & 2.1 \\
\hline equid & 4 & $<1.0$ & 1 & $<1.0$ & 0 & 0.0 & 7 & $<1.0$ \\
\hline other & 87 & 4.0 & 8 & 2.2 & 27 & 3.2 & 130 & 3.3 \\
\hline Total & 2191 & 100.0 & 364 & 100.0 & 854 & 100.0 & 3921 & 100.0 \\
\hline
\end{tabular}

Table 4. Relative frequency of mammalian taxa at Erbaba based on bone weight. 'Other' includes carnivores, hare and rodents.

\begin{tabular}{|c|c|c|c|c|c|c|c|c|}
\hline & \multicolumn{2}{|c|}{ I } & \multicolumn{2}{|c|}{ II } & \multicolumn{2}{|l|}{ III } & \multicolumn{2}{|c|}{ All levels } \\
\hline & weight (g) & $\%$ & weight (g) & $\%$ & weight (g) & $\%$ & weight (g) & $\%$ \\
\hline caprines & $14,099.9$ & 48.8 & 2174.2 & 39.2 & 5380.3 & 62.2 & $24,670.0$ & 50.9 \\
\hline cattle & 7078.7 & 24.5 & 1864.8 & 33.6 & 1737.1 & 20.1 & 11525.0 & 23.8 \\
\hline pig & 3889.4 & 13.4 & 776.2 & 14.0 & 604.7 & 7.0 & 5593.3 & 11.5 \\
\hline red deer & 2800.2 & 9.7 & 542.2 & 9.8 & 758.8 & 8.8 & 4926.0 & 10.2 \\
\hline $\begin{array}{l}\text { fallow and } \\
\text { roe deer }\end{array}$ & 485.0 & 1.7 & 140.7 & 2.5 & 71.1 & $<1.0$ & 894.1 & 1.8 \\
\hline equid & 132.0 & $<1.0$ & 20.2 & $<1.0$ & 0.0 & 0.0 & 230.8 & $<1.0$ \\
\hline other & 410.0 & 1.4 & 31.9 & $<1.0$ & 96.0 & 1.1 & 598.9 & 1.2 \\
\hline Total & $28,895.2$ & 100.0 & 5550.2 & 100.0 & 8648.0 & 100.0 & $48,438.1$ & 100.0 \\
\hline
\end{tabular}

taxonomic group in the assemblage after caprines and pigs, representing $c .5$ per cent of the assemblage based on counts of specimens identified to the genus level, and 23.8 per cent of the assemblage based on bone weight (Tables 3 and 4). Thus, although the number of remains is relatively small, cattle represent a central component of the subsistence system at Erbaba. 
The relative frequency of cattle remains changes little through the stratigraphic sequence at Erbaba, but the ratio of caprines and cattle, the two most important taxonomic groups based on bone weight, shifts markedly over time. The ratio of caprines to cattle in level III, the oldest level at Erbaba, is 21:1 but decreases to 8:1 and 13:1 in levels II and I, respectively, indicating that cattle became an increasingly important part of a more diverse economy in the uppermost levels of the site.

\section{LSI analysis}

It has long been recognised that domestic ungulates, including cattle, exhibit a reduced body size compared to their wild counterparts (Rütimeyer 1862; Röhrs \& Herre 1961; Ducos 1968; Grigson 1989). Reduced size may be recognised in archaeofaunal assemblages from measurements of individual skeletal elements and LSI values. In the log size index (LSI) method, log transformed measurements taken from archaeological specimens representing multiple skeletal elements are compared with those from a standard animal; in this case a large female aurochs from Mesolithic Denmark (following Grigson 1989; de Cupere \& Duru 2003; Russell \& Martin 2005). Although there are some potential problems with using an animal from a different region as the standard, including the potential for non-allometric variation in skeletal dimensions between the standard and the archaeological population (Meadow 1999; Zeder 2001; Russell et al. 2005), recent work in the region has shown these problems to be relatively minor (Russell \& Martin 2005).

LSI values for Erbaba cattle are much smaller than those from morphologically wild populations from PPNA Göbekli Tepe, EPPNB Nevalı Çori, aceramic Aşıklı and Suberde, and the early levels (pre-XII to IV) of Çatalhöyük, indicating the presence of morphological domesticates. Comparison of LSI values within the Erbaba assemblage indicates that although median values are largest in level III $\left(\mathrm{LSI}_{\text {medianIII }}=0.006 ; n=9\right)$ and decrease through time in levels II and I $\left(\mathrm{LSI}_{\text {medianII }}=-0.071, \mathrm{n}=15 ; \mathrm{LSI}_{\text {medianI }}=-0.037, \mathrm{n}=32\right)$, Mann-Whitney $\mathrm{U}$ tests, and a one-way ANOVA test indicate that these differences within the assemblage are not significant $(\mathrm{p}>0.05)$. Summaries of LSI values presented in Figure 2 compare the size of cattle from Erbaba with other Neolithic sites in central Turkey and the middle Euphrates region.

Figure 3 provides a more detailed look at the distributions of LSI values for Neolithic sites specific to central Anatolia. The village site of Aşıklı and the nearby special purpose site of Musular represent an early phase in the Neolithic occupation of central Anatolia (c. 8400$7200 \mathrm{cal}$ BC) and cattle remains recovered from these settlements represent morphologically wild populations (Russell et al. 2005). Cattle LSI values from the early levels of Çatalhöyük, including pre-XII $(c .7400-7000 \mathrm{cal} \mathrm{BC})$, XII-VII $(c .7000-6500 \mathrm{cal} \mathrm{BC})$, and VI-IV (c. 6500-6300 cal BC), show no evidence for a decrease in size relative to the Aşıklı/Musular populations, although a shift in the sex ratio is visible in levels VI-IV, with an increase in the representation of smaller, presumably female, animals relative to the earlier levels at Çatalhöyük (Russell et al. 2005: 104).

LSI data generated from the Mellaart excavations representing the upper levels VII-I at Çatalhöyük, but primarily representing levels III and II (Russell et al. 2005: 104) (c. 6500$6000 \mathrm{cal} \mathrm{BC}$ ) indicate the first appearance of small-sized specimens that fall significantly 
Table 5. Matrix showing the results of two-tailed Mann-Whitney $U$ tests comparing LSI values between assemblages. Significant differences are listed in bold type. Çatal 1 represents levels pre-XII through IV, while Çatal 2 represents levels VII-I.

\begin{tabular}{lccrrr}
\hline & & Çatal 1 & \multicolumn{1}{c}{ Çatal 2 } & Höyücek & Sabi Abyad \\
\hline Erbaba & $\mathrm{U}$ & 4756 & 5626.5 & 3376 & 7441 \\
& $\mathrm{z}$ & 7.67 & -0.73 & 2.49 & -1.89 \\
& $\mathrm{p}$ & $\mathbf{< . 0 0 0 1}$ & 0.4654 & $\mathbf{0 . 0 1 2 8}$ & 0.0588 \\
Çatal 1 & $\mathrm{U}$ & - & 4063.5 & 1999 & 4014.5 \\
& $\mathrm{z}$ & - & 7.06 & 8.94 & 8.87 \\
& $\mathrm{p}$ & - & $\mathbf{< 0 . 0 0 0 1}$ & $\mathbf{< 0 . 0 0 0 1}$ & $<\mathbf{0 . 0 0 0 1}$ \\
\hline
\end{tabular}

$\begin{array}{ccccccccc}\text { Göb } & \text { NÇ } & \text { Ası } & \text { Sub } & \text { Çat 1 } & \text { Çat 2 } & \text { Erb } & \text { Höy } & \text { Sabi } \\ \text { (PPNA) } & (\text { EPPNB }) & (\text { MPPNB }) & (\text { LPPNB }) & (\text { PPNB/PN) } & (P N) & (P N) & (P N) & (\text { PN) }\end{array}$

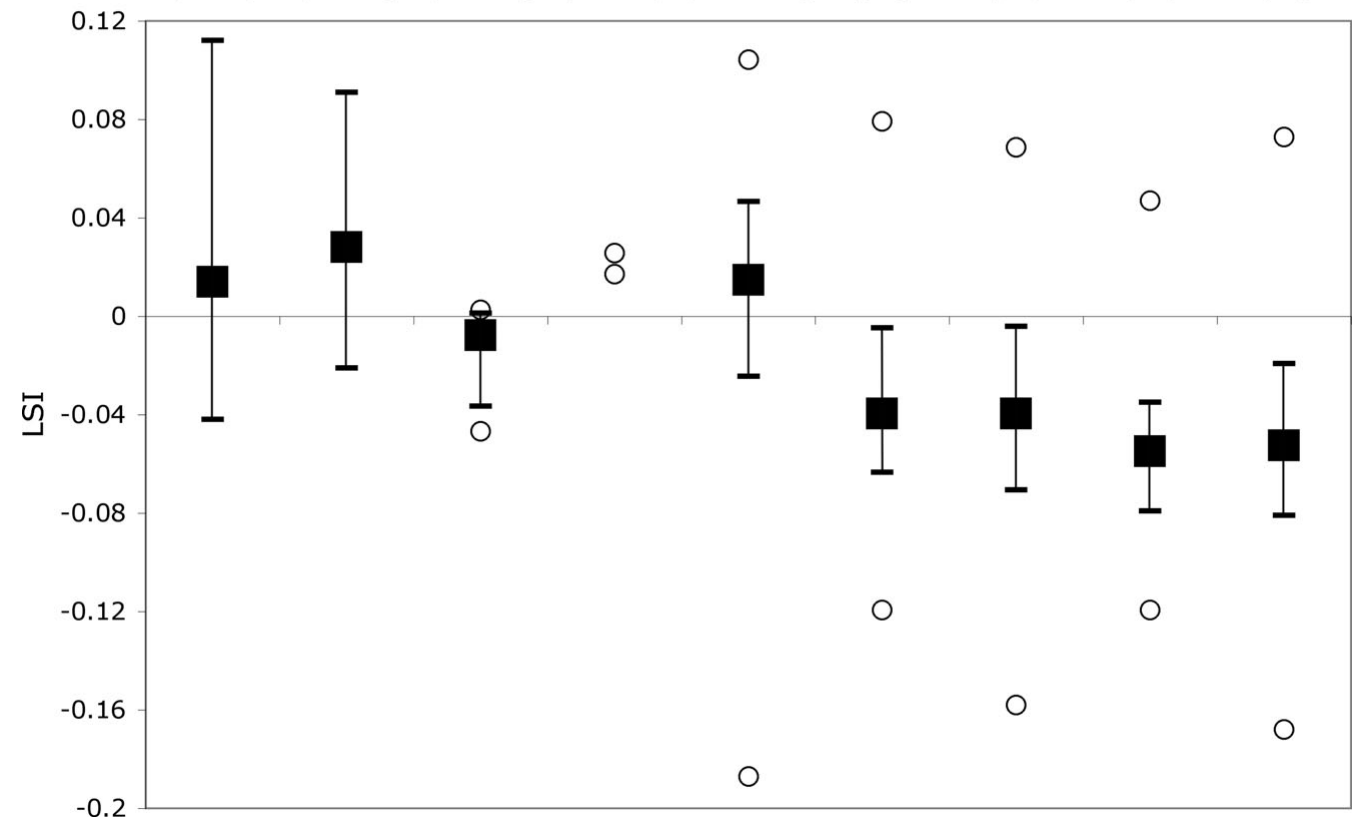

Figure 2. Plots showing median, inter-quartile range, and maximum and minimum LSI values for cattle including. Göb=Göbekli Tepe $(n=51)$ (Peters et al. 1999); NÇ=Nevalı Çori $(n=13)$ (Peters et al. 1999); Ast=Ašlklı Höyük $(n=7)$ (Payne 1985); Sub= Suberde ( $n=2)$ (Perkins 1969); Çat $1=$ Çatalhöyük pre-XII to IV $(n=179)$ (Russell \& Martin 2005); Çat 2 = Çatalhöyük VII-I $(n=94)$ (Ducos 1988); Erb = Erbaba $(n=113) ;$ Höy = Höyücek $(n=76)($ de Cupere \& Duru 2003); Sabi = Sabi Abyad ( $n=115$ ) (Cavallo 2000).

below the size range documented in earlier levels at the site (see Table 5). Equally small-sized cattle are also present at Erbaba (c. 6600-6100 cal BC), and at Höyücek (c. 6400/6200$6000 \mathrm{cal}$ BC) (Figure 3) indicating a significant decline in cattle size throughout the region in the late seventh millennium BC. The wide range of LSI values present at Erbaba and in the uppermost levels of Çatalhöyük suggests the continued presence of wild cattle in those assemblages. At Höyücek, however, a majority of specimens fall below the lower end of the 

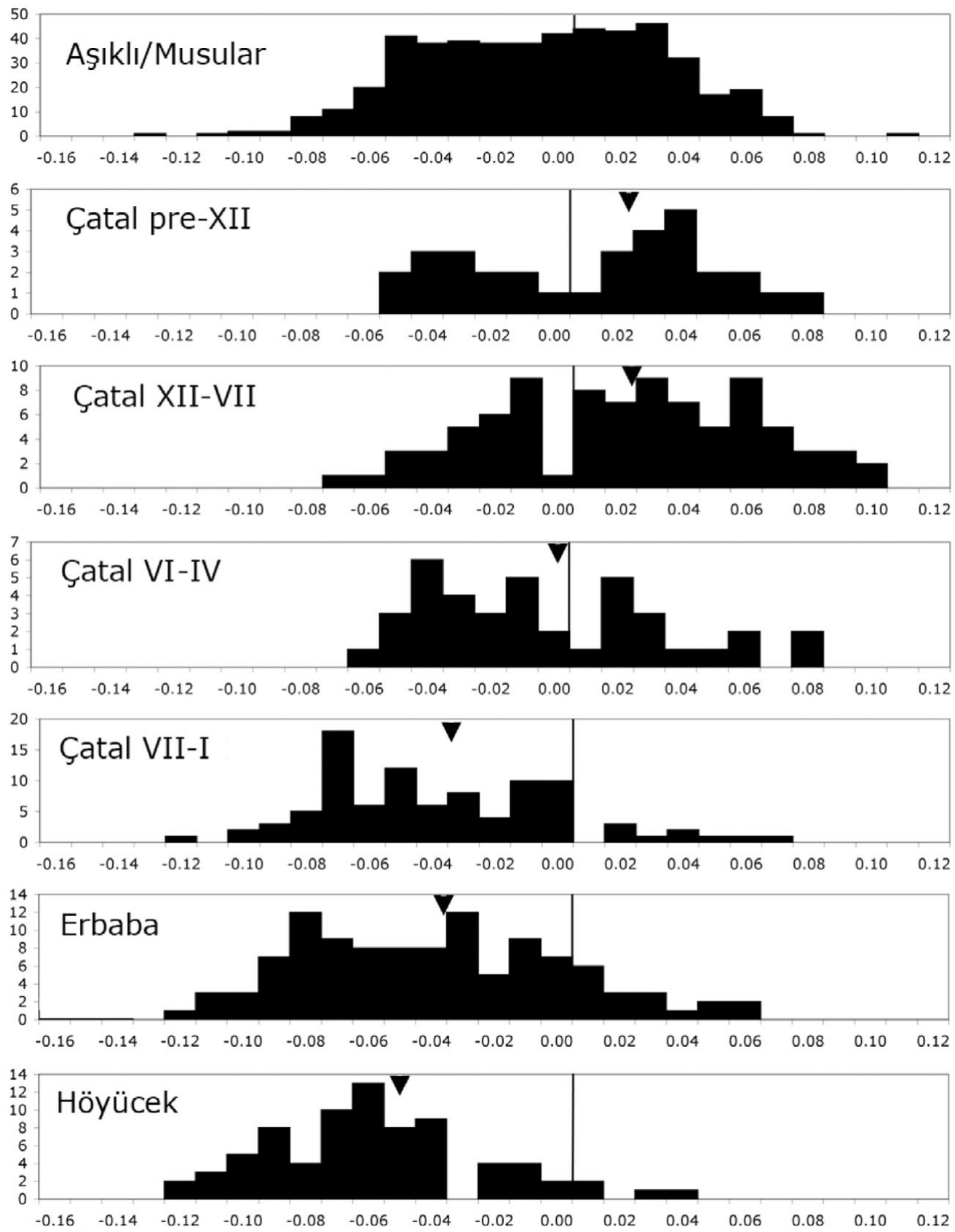

Figure 3. Distributions of LSI values for cattle from central Anatolian sites. Black triangles indicate location of median value (not available for Aşılı/Musular). 


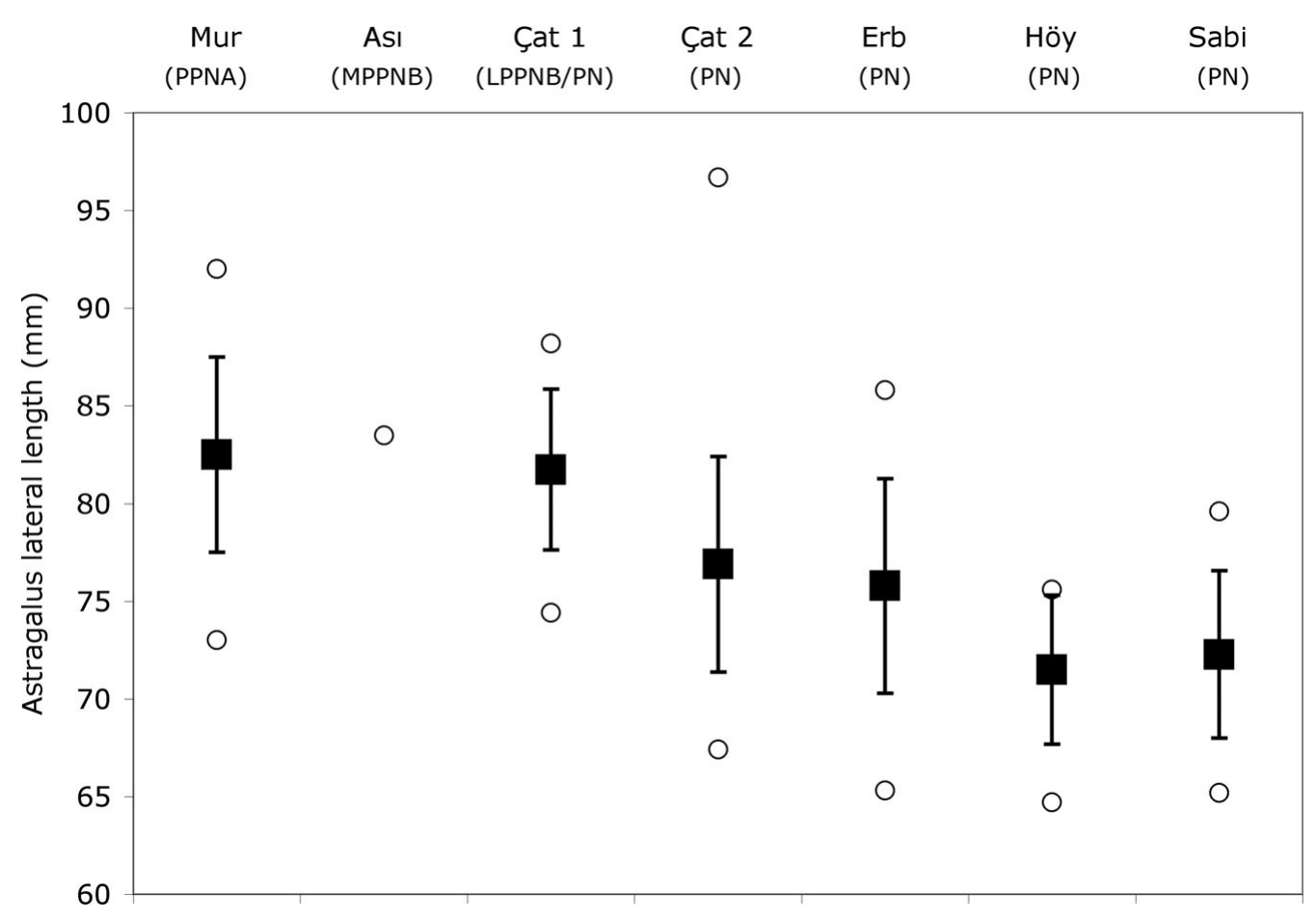

Figure 4. Mean, one standard deviation range, and maximum and minimum values for astragalus length measurements for cattle. Mur= Mureybet $(n=14)$ (Helmer 1994); Ası=Aşılı $(n=1)$ (Payne 1985); Çat $1=$ Çatalhöyük pre-XII to IV $(n=11)$ (Russell \& Martin 2005); Çat 2= Çatalhöyük VII-I $(n=63)$ (Ducos 1988); Erb=Erbaba $(n=21)$; Höy = Höyücek $(n=13)$ (de Cupere \& Duru 2003); Sabi=Sabi Abyad $(n=15)$ (Cavallo 2000).

size range of wild cattle (c. -0.06 on the LSI scale) and specimens in the size range of bull aurochsen are rare.

Biometric results based on LSI values are supported by measurements of the length of the astragalus, the most abundant single measurement in the assemblage (Figure 4). Measurements from Erbaba cattle are considerably smaller than those obtained from Mureybet, Aşıkl, and the early levels of Çatalhöyük, assemblages thought to represent wild populations (Payne 1985; Ducos 1988; Russell et al. 2005). While still including some very large specimens, the data from the upper levels of Çatalhöyük and Erbaba exhibit much smaller mean values than those from earlier sites and are similar to those representing domestic cattle from Late Neolithic Höyücek and Sabi Abyad.

It is unlikely that the size diminution observed in central Anatolian cattle is due to shifts in environmental conditions over time or geographical differences. There is no evidence for change in the body size of red deer from sites in central and south-eastern Turkey from the PPNA through the Pottery Neolithic (see Figure 5). Mann-Whitney U tests as well as a one-way ANOVA $(\mathrm{F}=0.51, \mathrm{df}=132, \mathrm{p}=0.73)$ indicate no significant differences between the LSI values for these populations. The absence of size diminution in red deer over a long temporal sequence supports the conclusion that the decrease in cattle size seen in central Anatolia during the seventh millennium is largely due to human management rather than environmental inputs selecting for smaller body size in wild populations. 


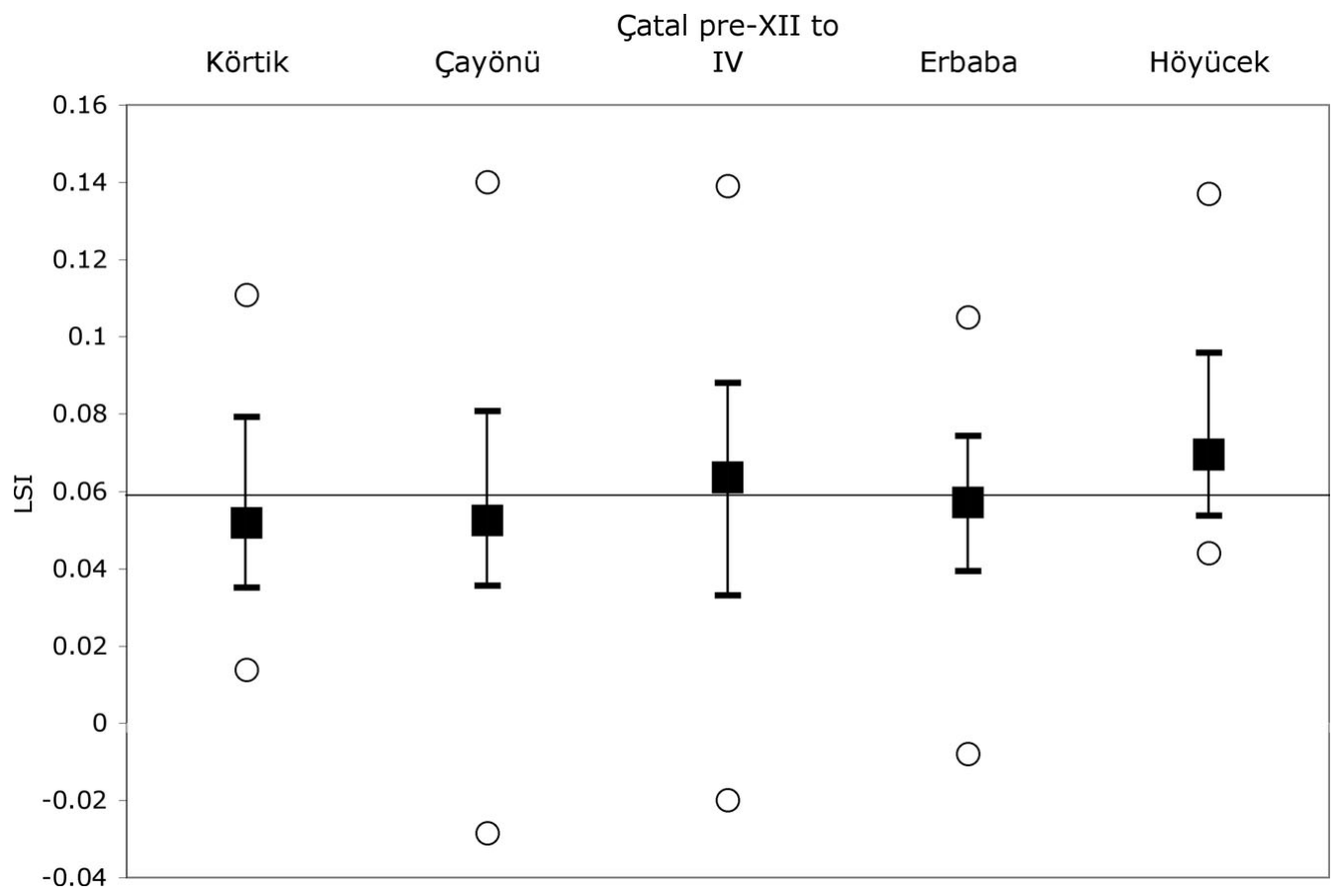

Figure 5. Plots showing median, inter-quartile range, and maximum and minimum LSI values for red deer from Körtik Tepe (Arbuckle \& Ozkaya 2006), Çayönü (Ilgezdi 2000), Çatalhöyük (Russell \& Martin 2005), Erbaba and Höyücek (de Cupere \& Duru 2003).

\section{Survivorship analysis}

Demographic data are presented in Figure 6 in the form of survivorship curves generated from the state of fusion of long bone epiphyses. Demographic profiles are useful tools for documenting the origins of cattle herding (Hesse 1982; Horwitz et al. 1999). In many cases, the management of domestic animals produces survivorship curves dominated by the remains of immature individuals, usually young males, while hunting often (but not always) produces demographic patterns with higher frequencies of mature individuals often with an over-representation of large males. Although these patterns can be broadly useful in differentiating strategies of hunting and herding, variables such as the intensity and seasonality of hunting, management for milk and traction, as well as exploitation strategies that include components of both herding and hunting often make the interpretation of demographic patterns difficult (Meadow 1989; Arbuckle 2008).

Survivorship data indicate a significant focus on the slaughter of immature cattle at Erbaba, with only 55 per cent of the sample surviving past the age of fusion of the metapodials ( $c$. 24 months) and calcaneus (c.36 months), and $c .45$ per cent surviving past the age of fusion of the latest fusing skeletal parts (c. 48 months) (Silver 1969). In addition, the ratio of deciduous, mandibular fourth premolars to third molars (6:8) confirms the results of long bone fusion suggesting that a relatively high proportion of cattle at Erbaba were slaughtered as juveniles. In contrast, a survivorship curve constructed for red deer indicates that most of 


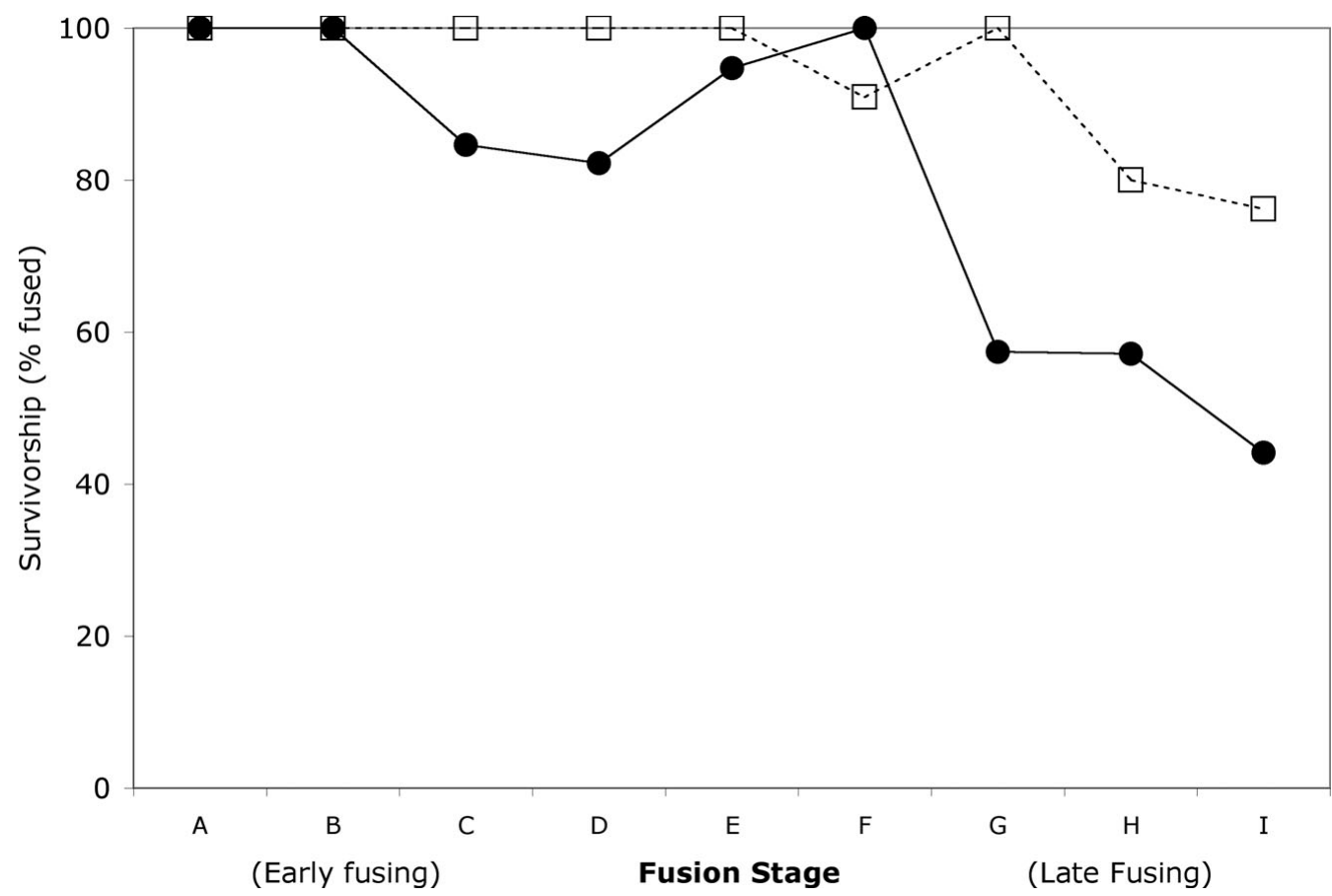

Figure 6. Survivorship curves for cattle (solid line) and red deer (dotted line) from Erbaba. Fusion stage A = distal scapula; $B=$ proximal radius; $C=$ distal humerus; $D=$ proximal first phalanx; $E=$ proximal second phalanx; $F=$ distal tibia; $G=$ distal metapodials; $H=$ calcaneus; $I=$ distal radius, proximal tibia, proximal femur, distal femur.

these animals were slaughtered as prime-aged adults, with almost 80 per cent surviving past the age of fusion of the latest fusing skeletal parts (>36 months).

Intensive culling of juvenile cattle in their first and second years of life at Erbaba is similar to the pattern seen at Çatalhöyük, where $c .40-50$ per cent of individuals were slaughtered as juveniles and/or infants throughout the entire stratigraphic sequence (Ducos 1988; Russell \& Martin 2005). However, the frequency of infantile remains at Erbaba (c. 15 per cent) is considerably lower than at Çatalhöyük (21-33 per cent), although this may at least partially be an artifact of the more effective recovery of small, unfused specimens at the latter site.

\section{Skeletal part distribution}

Skeletal part representations are useful for interpreting the mode of animal exploitation employed at a site, especially for large mammals, whose carcasses are laborious to transport (Perkins \& Daly 1968; Becker 2002). The presence of all portions of a large mammal carcass suggests an economy based on domesticates in which animals are readily available and are slaughtered and butchered onsite. Conversely, high frequencies of so-called high utility skeletal parts (e.g. proximal portions of limbs) representing concentrations of useful resources (e.g. meat, marrow, bone grease, etc.) and under-representation of lower utility skeletal parts (e.g. feet and heads) has been associated with hunting practices in which animals are slaughtered and butchered away from the site and only the most useful parts are transported back to the site itself (Perkins \& Daly 1968; Vigne et al. 1999). Based on 


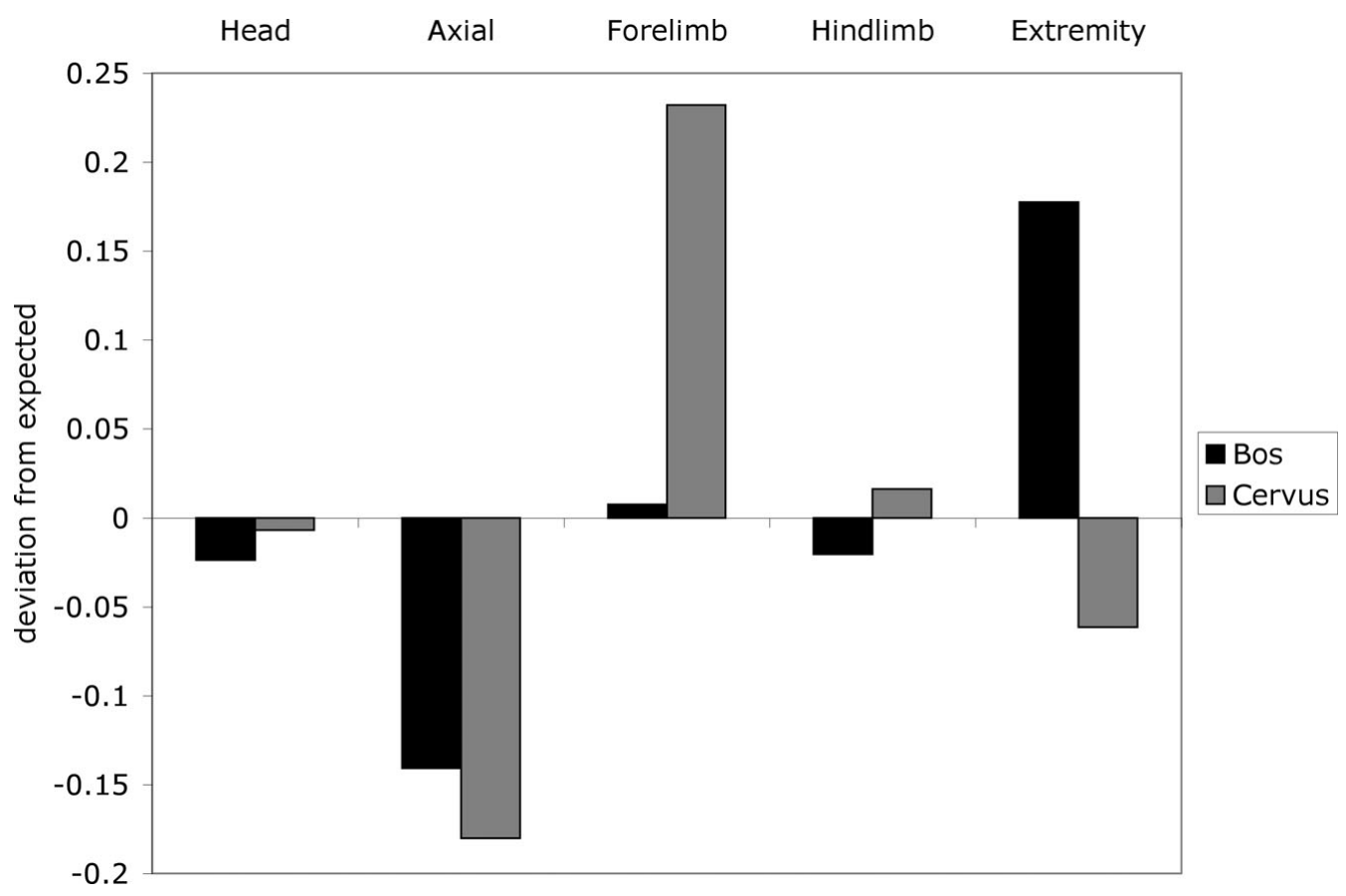

Figure 7. Deviations from the expected frequencies of skeletal elements in a complete ungulate skeleton for cattle $(n=415)$ and red deer $(n=284)$ from Erbaba.

this model, the presence of lower utility skeletal parts, especially head and foot remains, indicating onsite butchery and slaughter of cattle, may serve as a proxy for identifying systems of cattle management.

A summary of the representation of skeletal parts is presented in Figure 7 for both cattle and red deer. This graph presents deviations from the expected frequencies of skeletal parts in a complete ungulate skeleton for five anatomical regions including the head, axial skeleton, forelimb, hindlimb and extremities. These values are produced by calculating the minimum number of skeletal elements (MNE) and standardising first in reference to the number of elements present in a skeleton (Binford's [1984] MAU) and then for each anatomical region (Stiner 1994: 240; Arbuckle 2006). A value above zero on this graph indicates that the elements of a given anatomical region are over-represented in proportion to their frequency in a complete carcass, while negative values indicate under-representation.

Comparison of the representation of anatomical regions shows that patterns for cattle and red deer at Erbaba differ significantly both from the expected values and from each other. For cattle, a Kolmogorov-Smirnov one sample test indicates that the representation of anatomical regions differs significantly from that expected in a complete carcass $(D=0.154$, $\mathrm{n}=93, \mathrm{p}<0.05)$. Elements of the head and hindlimb are slightly under-represented, whereas elements of the forelimb are slightly over-represented. The most dramatic deviations from expected skeletal proportions for cattle are observed in the axial skeleton, the elements of which are highly under-represented, and the distal extremities (i.e. feet), which are highly over-represented. The under-representation of axial elements is likely due to the low density 
of axial skeletal elements, which tend not to survive taphonomic processes such as cooking and carnivore gnawing, evidence of which is abundant in the Erbaba faunal assemblage (see Arbuckle 2006). The great abundance of foot elements, however, is not related to density-mediated attrition and thus probably reflects human behaviors associated with the butchery and disposal of cattle remains. The abundance of foot elements likely indicates that primary butchery of cattle carcasses took place near the site, a conclusion that fits with the interpretation of Erbaba cattle as a domestic population (although see Perkins \& Daly 1968; Marciniak 2005).

The representation of skeletal elements for red deer differs from that for cattle in important ways, indicating that skeletal part frequencies are not simply the result of taphonomic processes affecting the remains of all large mammals, but instead represent differences in the exploitation of deer versus cattle. For red deer, elements of the forelimb and hindlimb are over-represented while elements of the head, distal extremities, and axial skeleton are under-represented (Figure 7). As with cattle, the under-representation of the red deer axial skeleton may be due to density mediated attrition while the high concentrations of meat rich fore- and hindlimbs, and the under-representation of nutrient poor heads and feet likely reflect carcasses processing strategies employed by Erbaba hunters. This evidence suggests that, in contrast to cattle, red deer were hunted and field processed at some distance from the settlement, with only the most useful portions of the skeleton being brought back to the site for further processing.

\section{Cattle at Çatalhöyük}

Prior to the availability of new data from Erbaba, zooarchaeological evidence for early cattle exploitation in central Anatolia had been largely limited to the faunal assemblage recovered from Çatalhöyük. Analyses of the Çatalhöyük fauna conducted by Perkins (1969) documented a high frequency of cattle remains in the faunal assemblage $(c .75$ per cent of the collected fauna), representation of all portions of the cattle skeleton, and size diminution in level VI ( $c .6500 \mathrm{cal}$ BC), suggesting that domesticated cattle were present at the site from an early date. New research, however, has forced a re-evaluation of the status and processes of cattle domestication at Çatalhöyük and in central Anatolia in general.

Contrary to Perkins' initial results, cattle are not unusually abundant at Çatalhöyük, constituting only $c .15$ per cent of the total faunal remains, and size diminution, the evidence for which seems to have been based on methodological errors (Grigson 1989; Russell \& Martin 2005), is not evident in the cattle remains in the lower levels. Moreover, comparison of metrical data from Çatalhöyük with those from morphologically wild cattle populations from two earlier aceramic sites in central Anatolia, Aşıklı Höyük and Musular, indicate that cattle from the lower levels (pre-XII through IV) at Çatalhöyük are similar to, or slightly larger in body size than cattle from those earlier sites (Russell et al. 2005).

Demographic data generated for cattle recovered from the lower levels at Çatalhöyük also indicate that a high proportion of prime-aged adults and large males were slaughtered by the inhabitants of the site, suggesting that cattle were hunted, not herded, at Çatalhöyük between 7400-6300 cal BC (levels pre-XII through IV) (Russell \& Martin 2005). In addition, at aceramic Suberde, a settlement located less than $100 \mathrm{~km}$ from both Çatalhöyük and Erbaba, 
demographic data indicating a focus on slaughtering prime-aged adults and metrical data falling within the size range of Near Eastern aurochsen suggest that wild cattle were also exploited in the Beyşehir region of central Anatolia throughout the early Neolithic ( $c$. 7500-7000 cal BC) (Perkins \& Daly 1968; Perkins 1969).

Analyses of fauna representing the latest phases of the Neolithic settlement at Çatalhöyük (Levels VII-I; 6500-6000 cal BC), recovered from the earlier Mellaart excavations, further reveals important diachronic shifts in cattle exploitation at the site (Ducos 1988). Tooth eruption and wear data indicate an increase in juvenile kill-off compared to the lower levels, with 40 per cent of cattle slaughtered between 0-2 years of age in the latest levels (Ducos 1988: 87). Cattle remains recovered from the upper levels of Çatalhöyük are also considerably smaller than those from the earlier levels, with individuals falling well below the size range of Near Eastern aurochsen appearing for the first time. Since morphological domesticates have not been identified in recent work at the site through level IV, these data suggest that morphologically domestic cattle make their first appearance at Çatalhöyük some time in the latest levels, between 6300-6000 cal BC.

\section{Autochthonous and diffusionary domestication processes}

Distinguishing between autochthonous domestication processes and the diffusion of domestic animals into a region from an outside source assumes that these processes are each characterised by distinctive trends observable in the biometrical and demographic data produced by each process. Although it is recognised that there is the potential for variation extending outside of this binary framework, it is argued that these models provide useful points of departure for more detailed discussions of the complex processes responsible for the emergence of cattle management in Anatolia.

For those faunal assemblages produced by bringing local, wild populations under human control, the expectation is that these samples will be characterised by a gradual shift in skeletal morphology and biometrics, a process which may extend over a millennium or more as the introduction of management practices and anthropogenic selective pressures slowly transform wild populations into phenotypically domestic ones.

Zooarchaeological evidence derived from several sites across the Near East, each exhibiting great temporal depth, supports this model, linking together gradual morphological change in animal populations and in situ domestication processes. At Merhgarh, a large Neolithic settlement located on the eastern margin of the Near East in Pakistani Balochistan, biometric data document a gradual process of size diminution in cattle recovered from deposits spanning the Neolithic period (c.7000-4000 cal BC). By the end of the Neolithic, Mehrgarh cattle exhibit skeletal dimensions that fall well below those of wild aurochs suggesting local domestication processes (Meadow 1981, 1984, 1993). Similarly, a pattern of gradual reduction in body size is seen in cattle at Çayönü Tepesi, south-eastern Turkey, with the proportion of small, domestic-sized animals increasing slowly over time from the Channeled Building sub-phase (Middle PPNB, c. 8300-7500 cal BC) through the Pottery Neolithic levels (c. $6000 \mathrm{cal} \mathrm{BC)} \mathrm{(Hongo} \mathrm{et} \mathrm{al.} \mathrm{2002,} \mathrm{2004).}$

In contrast, diffusion models describing the appearance of domesticated animals predict that morphologically domestic individuals will appear abruptly in assemblages 
previously dominated by wild forms, with little evidence for transitional morphologies. Zooarchaeologically, this process may be evident in the form of bimodal or 'peak and tail' distributions in biometric data indicating the presence of biometrically distinctive wild and domestic populations (Hachem 2001; Becker 2002; Albarella et al. 2006).

The abrupt appearance of small-sized cattle in European Neolithic cultures such as the Linearbandkeramik (LBK), combined with the continued presence of robust aurochsen and absence of transitional skeletal morphologies linking these populations, suggests that these domesticates were introduced via human migration and trade (Hachem 2001; DeschlerErb \& Marti-Grädel 2004; Dobney \& Larson 2006; Edwards \& Bollongino 2007; Scheu et al. 2008). Comparable biometrical trends identified in cattle remains from southern Levantine contexts have similarly been used in support of diffusionist models for the appearance of domestic cattle during the Late PPNB (c. 6500 cal BC) (Becker 2002).

Although the autochthonous and diffusionist models described above are commonly employed by zooarchaeologists, differentiating between the processes of diffusion and local domestication is likely to be difficult, particularly if the dispersal of managed animals occurred during the earliest stages of the domestication process when phenotypic divergence is weakly expressed or completely lacking. The diffusion of phenotypically 'primitive' managed cattle may present characteristics of both models, including the rapid appearance of morphological domesticates but the continued presence of many individuals with transitional morphologies that fall within the area of overlap between wild and domestic populations. Alternatively, if the radiation of husbanded animals took place prior to the expression of any morphological changes, as may have been the case in the early Neolithic of Cyprus (Vigne et al. 2003), then other lines of evidence, including demographic data and skeletal part representations, must be assessed in order to distinguish between local domestication and diffusionist processes (e.g. Perkins \& Daly 1968; Hesse 1978; Zeder 2006, 2008).

\section{Discussion}

Isolating the processes responsible for the initial appearance of morphologically domestic cattle in central Anatolia and establishing whether it represents the beginnings of cattle management in the region are complex problems. Given the prominent role of cattle at aceramic and early Pottery Neolithic sites in the region (Russell et al. 2005), and the evidence for diachronic changes in cattle exploitation in the Çatalhöyük stratigraphic sequence, local processes must be seriously considered as a possible explanation for the appearance of domestic cattle in central Anatolia. Moreover, since the origins of herd management are thought to predate the appearance of morphological changes by some considerable period of time (Zeder 2006), the relatively late appearance of morphologically domestic cattle in the region does not necessarily mean that cattle husbandry was a late development as well.

Although the lack of detailed information describing the faunas recovered from aceramic sites such as Aşıklı and Musular inhibits our ability to interpret cattle management in the early Neolithic, the data that are currently available do not suggest that cattle were intensively managed in central Anatolia prior to the appearance of morphological domesticates at Erbaba at c. 6600 cal BC (Perkins \& Daly 1968; de Cupere \& Duru 2003; Russell et al. 2005; Zeder 2008). It is possible that the changes in cattle exploitation documented in levels VI-IV 
at Çatalhöyük, just prior to the appearance of domestic cattle, may reflect the early stages of a process of intensified management of wild cattle populations that, if left to develop uninterrupted, may have eventually led to the emergence of local domesticates (but see Russell \& Martin 2005). If so, this local process seems to have been truncated by the abrupt appearance of domesticates on the Konya Plain and in other parts of central Anatolia in the mid-seventh millennium.

Unlike the situation at Merhgarh or Çayönü, where biometric data indicate a gradual decrease in cattle size over a period of several millennia, suggesting local domestication processes, the abrupt appearance of small-sized cattle at Erbaba, in the upper levels of Çatalhöyük, and at Höyücek in south-west Anatolia within the same narrow time horizon provides little time depth for a process of local domestication. This strongly suggests that the earliest morphologically domestic cattle in central Anatolia derive from previously domesticated populations from neighbouring regions. In addition, the identification of morphologically domestic cattle populations predating those in central Anatolia from sites such as Yumuktepe on the southern coast of Anatolia and Gürcütepe and Halula in the northern Levant provide plausible sources for imported domesticated animals (Buitenhuis \& Caneva 1998; Peters et al. 1999; von den Driesch \& Peters 1999). The presence of wellworn trade networks involved in the movement of obsidian, Mediterranean shells, and other commodities confirms that central Anatolians were regularly engaged with other human populations throughout the Near East (Bar-Yosef 2001; Asouti 2006). Indeed, trade networks may have served as important conduits through which domestic cattle were transported and exchanged.

Although the rapid appearance of morphological domesticates in central Anatolia fits the predictions outlined by diffusion models, the persistence of a high degree of variation in body size and the presence of both very large and small cattle at Erbaba and Çatahöyük VII-I differs from examples of secondary diffusion of domesticates in regions such as Europe. This may be the result of several factors. First, the presence of specimens exhibiting a wide range of sizes in the Erbaba and Çatalhöyük VII-I assemblages may be indicative of the diffusion of phenotypically 'primitive' domesticates, which do not exhibit as great a degree of phenotypic divergence from wild populations as do domesticates in later periods (e.g. Grigson 1989). However, given the small size and relatively low range of variation in biometric data evident among domestic cattle at the contemporary site of Höyücek, the arrival of primitive domestic cattle in central Anatolia does not explain the full range of metrical variability visible in the Erbaba and Çatalhöyük assemblages.

Instead, the continued presence of many large-sized cattle at these sites likely indicates a continued exploitation of aurochsen, animals which may have not only served as supplements to the subsistence economies at these settlements, particularly during the early stages of incorporating domestic cattle into local subsistence systems, but also may have played an important role in social practices as well. At Çatalhöyük, the hunting of aurochs featured in various socio-cultural practices for a millennium prior to the appearance of cattle herding (Mellaart 1967; Meskell 2008), and evidently continued alongside herding as an important part of the maintenance and management of social and political relationships within this community. The apparent delay of several centuries between the appearance of domestic cattle at Erbaba and their adoption at Çatalhöyük may be related to the central role of 
aurochs hunting at the latter settlement. Some of the inhabitants of Çatalhöyük, whose social position and identity may have been maintained by and deeply embedded within the practices surrounding cattle hunting, may have actively resisted the ideological as well as economic changes associated with incorporating cattle into the domestic sphere.

Finally, the continued presence of morphologically wild cattle at Erbaba and Çatalhöyük after the adoption of cattle herding may be due to breeding practices that included the recruitment of local aurochsen into managed herds (Götherstrom et al. 2005; Beja-Pereira et al. 2006). The presence at Çatalhöyük of wall-paintings that may depict captured wild cattle (Mellaart 1967: Plate 64; Hodder 2006: Plate 15), suggests that Neolithic hunters may have at least occasionally brought aurochsen under control in order to provide high value and symbolically powerful animals for specific cultural events. If this highly risky and presumably socially rewarding behaviour continued following the importation of domestic cattle at the site, it is possible that wild individuals, especially bulls, were allowed or encouraged to breed with domestic females, a practice that would effectively reduce the pace of phenotypic divergence within those domestic populations.

\section{Conclusion}

Although no longer considered to be an early centre for cattle domestication, central Anatolia remains an important region for documenting the initial spread of managed cattle outside of the middle Euphrates region and for assessing the modes and mechanisms by which domestic cattle became incorporated into local Neolithic economies. The combination of size diminution, harvesting of juvenile animals, and on-site butchering of cattle at Erbaba suggest that domestic cattle make their first appearance in central Anatolia by c. $6500 \mathrm{cal} \mathrm{BC}$. The use of morphologically domestic cattle in south-western Anatolia by 6400/6200 cal BC (de Cupere \& Duru 2003), and to the east on the Konya Plain between 63006000 cal BC suggests a rapid incorporation of domestic cattle into central Anatolian subsistence economies that had been previously characterised by large-scale sheep and goat herding for more than a millennium (Martin et al. 2002; Russell \& Martin 2005; Arbuckle 2006, 2008).

Although we acknowledge that the initiation of animal management practices likely preceded the expression of domestic phenotypes in managed populations, we argue that the appearance of morphologically domestic cattle at Erbaba, and slightly later at Çatalhöyük, represents the earliest use of husbanded cattle in central Anatolia. The assimilation of primitive domestic cattle into local Neolithic economies likely entailed a complex management strategy that involved the simultaneous use of husbanded animals, initially obtained via extra-local sources, and regular maintenance of domesticates by introducing local aurochs into managed herds. Significantly, deeply engrained local traditions centered on aurochs hunting persisted in central Anatolia, although on a smaller scale than practiced in previous periods. Moreover, the possibility that the appearance of domestic cattle in central Anatolia may have truncated the development of an autochthonous process of increasingly intensive management of wild cattle at Çatalhöyük further emphasises the importance of regional and intra-regional variation when addressing the development and spread of Neolithic technologies. 


\section{Acknowledgements}

Analysis of the Erbaba faunal assemblage was supported by the Zooarchaeology Laboratory, Harvard University as well as the Peabody Museum of Ethnology and Archaeology. Richard Meadow, Stine Rossel, Levent Atici, Peter Burns and Tonya Largy provided help in all stages of this research and this is gratefully acknowledged. Financial support for this research was provided by grants from the American Research Institute in Turkey, the University Research Committee and the Vice Provost for Research at Baylor University, and NSF Grant BCS-0530699. Biometric data for the Erbaba cattle are available by request (please contact Arbuckle).

\section{References}

Albarella, U., K. Dobney \& P.A. Rowley-Conwy. 2006. The domestication of the pig (Sus scrofa): new challenges and approaches, in M. Zeder, D.G. Bradley, E. Emschwiller \& B.D. Smith (ed.) Documenting domestication: new genetic and archaeological paradigms: 209-27. Berkeley (CA): University of California Press.

ARBUCKLE, B.S. 2006. The evolution of sheep and goat pastoralism and social complexity in Central Anatolia. PhD dissertation. Ann Arbor (MI): University Microfilms International.

- 2008. Caprine exploitation at Erbaba Höyük: a Pottery Neolithic village in Central Anatolia, in L. Gourichon \& E. Vila (ed.) Archaeozoology of southwestern Asia and adjacent areas VIII: 345-65. Paris: Travaux de la Maison de l'Orient.

ArbuCKLE, B.S. \& V. ÖZKaYA. 2006. Animal exploitation at Kortik Tepe: an early Aceramic Neolithic site in southeastern Turkey. Paléorient 32(2): 113-36.

Asouti, E. 2006. Beyond the Pre-Pottery Neolithic B interaction sphere. Journal of World Prehistory 20: $87-126$.

Bar-Yosef, O. 2001. The world around Cyprus: from Epi-Paleolithic foragers to the collapse of the PPNB civilization, in C. Swiny (ed.) Earliest prehistory of Cyprus: 129-64. Boston (MA): American Schools of Oriental Research.

BECKER, C. 2002. Nothing to do with indigenous domestication? Cattle from Late PPNB Basta, in H. Buitenhuis, A.M. Choyke, M. Mashkour \& A.H. Al-Shiyab (ed.) Archaeozoology of the Near East V. Proceedings of the fifth international symposium on the archaeozoology of southwestern Asia and adjacent areas (ARC Publication 62): 112-37. Groningen: Centre for Archaeological Research and Consultancy.

Beja-Pereira, A., D. Caramelli, C. Lalueza-Fox, C. Vernesi, N. Ferrand, A. Casoli, F. Goyache, L.J. Royo, M. Lari, A. Martini, L. Ouragh, A. Magid, A. Atash, A. Zsolnai, P. Boscato, C. Triantaphylidis, K. Ploumi, L. Sineo, F. Mallegni, P. Taberlet, G. Erhardt, L. Sampietro, J. Bertranpetit, G. Barbujani, G. LUIKART \& G. BERTORELLE. 2006. The origin of European cattle: evidence from modern and ancient DNA. Proceedings of the National Academy of Sciences 103: 8113-18.

BINFORD, L.R. 1984. Faunal remains from Klasies River mouth. New York: Academic Press.

Bordaz, J. \& L. Alper-BordAz. 1976. Erbaba excavations: activities through the 1974 field season. Türk Arkeoloji Dergisi 23: 39-43.

- 1982. Erbaba: the 1977 and 1978 seasons in perspective. Türk Arkeoloji Dergisi 26: 85-93.

BuITENHUIS, H. \& I. CANEVA. 1998. Early animal breeding in south-eastern Anatolia: Mersin-Yumuktepe, in P. Anreiter, L. Bartosiewicz, E. Jerem \& W. Meids (ed.) Man and the animal world: 122-30. Budapest: Archaeolingua.

Cavallo, C. 2000. Animals in the steppe: a zooarchaeological analysis of the Later Neolithic Tell Sabi Abyad, Syria (British Archaeological Reports International Series 891). Oxford: John \& Erica Hedges.

Cessford, C. 2001. A new dating sequence for Çatalhöyük. Antiquity 75: 717-25.

De Cupere, B. \& R. Duru. 2003. Faunal remains from Neolithic Hoyucek (SW Turkey) and the presence of early domestic cattle in Anatolia. Paléorient 29: 107-20.

Deschler-Erb, S. \& E. MARTI-GrÄDEL. 2004. Viehaltung und Jagd. Ergebnisse der Untersuchung def handaufgelesenen Tierknochen, in S. Jacomet, U. Leuzinger \& J. Schibler (ed.) Die jungsteinzeitliche Seeufersiedlung Arbon Bleiche 3. Umwelt und Wirthschaft: 158-252. Thurgau: Department fur Erziehung und Kultur des Kantons Thurgau.

Dobney, K. \& G. LARSON. 2006. Genetics and animal domestication: new windows on an elusive process. Journal of Zoology 269: 261-71.

Ducos, P. 1968. Lorigine des animaux domestique en Palestine (Publications de Prehistoire de l'Universite de Bordeaux 6). Bordeaux: Imprimeries Delmas.

- 1988. Archéozoologie quantitative: Les valeurs numériques immédiates a Çatal Hüyük. (Cahiers du Quaternaire 12). Paris: Centre National de la Recherche Scientifique Centre regional de publication de Bordeux.

EDWARDS, C. J. \& R. BOLlONGINO. 2007. Mitochondrial DNA analysis shows a Near Eastern Neolithic origin for domestic cattle and no indication of domestication of European aurochs. Proceedings of the Royal Society B 274: 1377-85. 
Götherstrom, A., C. Anderung, L. Hellborg, R. ElburG, C. Smith, D.G. Bradley \& H. ELLEGREN. 2005. Cattle domestication in the Near East was followed by hydridization with aurochs bulls in Europe. Proceedings of the Royal Society $B$ 272: $2345-50$.

GRIGSON, C. 1989. Size and sex: evidence for the domestication of cattle in the Near East, in A. Milles, D. Williams \& N. Gardner (ed.) The beginnings of agriculture (British Archaeological Reports International Series 496): 77-109. Oxford: British Archaeological Reports.

HACHEM, L. 2001. La conception du monde animal sauvage chez les eleveurs du Rubane, in R.-M. Arbogast, C. Jeunesse \& J. Schibler (ed.) Premieres recontres danubiennes Strasbourg, 20 et 21 novembre 1996. Actes de la premiere table ronde. Role et statut de la chasse dans la Neolithique Ancien Danubien (5500-4900 av. J.C.): 91-111. Rahden: Marie Leidorf.

Helmer, D. 1994. La domestication des animaux d'embouche dans le Levant nord Syrie du nord et Sinjar) du milieu du IXe millenaire BP à la fin du VIIIe millenaire BP. Nouvelles donnees d'apres les fouilles recents. Anthropozoologica 20: 41-54.

HESSE, B. 1978. Evidence for husbandry from the early Neolithic site of Ganj Dareh in western Iran. $\mathrm{PhD}$ dissertation. Ann Arbor (MI): University Microfilms International.

- 1982. Slaughter patterns and domestication: the beginnings of pastoralism in western Iran. Man 17: 403-17.

HODDER, I. 2006. The leopard's tale: revealing the mysteries of Catalhöyük. London: Thames \& Hudson.

Hongo, H., R.H. Meadow, B. OKsưz \& I. GÚlçIN. 2004. Animal exploitation at Çayönü Tepesi, southeastern Anatolia. Güneydogu Anadolu, Çayönü Tepesi'nde hayvanlardan yararlanılması. TÜBA-AR 7: 107-19.

Hongo, H., R.H. Meadow, B. OKsuz \& G. Ilgezdi. 2002. The process of ungulate domestication in Prepottery Neolithic Çayönü, southeastern Turkey, in H. Buitenhuis, A. M. Choyke, M. Mashkour \& A. H. Al-Shiyab (ed.) Archaeozoology of the Near East V. Proceedings of the fifth international symposium on the archaeozoology of southwestern Asia and adjacent areas (ARC Publication 62): 153-65. Groningen: Centre for Archaeological Research and Consultancy.

Horwitz, L.K. \& P. Ducos. 2005. Counting cattle: trends in Neolithic Bos frequencies from the southern Levant. Revue de Paléobiologie, Genève 10: 209-24.
Horwitz, L.K., E. Tchernov, P. Ducos, C. Becker, A. VON DEN Driesch, L. Martin \& A. Garrard. 1999. Animal domestication in the southern Levant. Paléorient 25: 63-80.

ILGEZDI, G. 2000. Zooarchaeology at Çayönü: a preliminary assessment of the red deer bones, in $\mathrm{H}$. Buitenhuis, M. Mashkour \& A. M. Choyke (ed.) Archaeozoology of the Near East IV. Proceedings of the fourth international symposium on the archaeozoology of southwestern Asia and adjacent areas. Part A (ARC Publications 32): 141-53. Groningen: Centre for Archaeological Research and Consultancy.

MAKAREWICZ, C. 1999. The faunal remains of Neolithic Erbaba: processes of domestication and the herding economy. Unpublished BA dissertation, Brandeis University.

MarciniaK, A. 2005. Placing animals in the Neolithic: social zooarchaeology of prehistoric farming communities. London: UCL Press.

Martin, L., N. Russell \& D. Carruthers. 2002. Animal remains from the Central Anatolian Neolithic, in F. Gerard \& L. Thissen (ed.) The Neolithic of Central Anatolia: internal developments and external relations during the 9th-6th millennia cal BC: 193-216. Istanbul: Ege Yayınları.

MEADOW, R.H. 1981. Early animal domestication in South Asia: a first report of the faunal remains from Merhgarh, Pakistan, in H. Hertel (ed.) South Asian archaeology 1979: 143-79. Berlin: Dietrich Reimer.

- 1984. Animal domestication in the Middle East: a view from the eastern margin, in J. Clutton-Brock \& C. Grigson (ed.) Animals in archaeology. Volume 3: Early herders and their flocks (British Archaeological Reports International Series 202): 309-37. Oxford: British Archaeological Reports.

- 1989. Osteological evidence for the process of animal domestication, in J. Clutton-Brock (ed.) The walking larder: patterns of domestication, pastoralism and predation: 80-96. London: Unwin Hyman.

- 1993. Animal domestication in the Middle East: a revised view from the eastern margin, in G.L. Possehl (ed.) Harappan civilization: a recent perspective: 295-320. New Delhi: American Institute of Indian Studies.

- 1999. The use of size index scaling techniques for research on archaeozoological collections from the Middle East, in C. Becker, H. Manhart, J. Peters \& J. Schibler (ed.) Historia animalium ex ossibus: Beitrage zur palaoanatomie, archaologie, agyptologie, ethnologie, and geschichte der tiermedizin: 285-300. Rahden: Marie Leidorf.

MellaArT, J. 1967. Çatal Hüyük: a Neolithic town in Anatolia. New York: McGraw-Hill.

MeSKELL, L. 2008. The nature of the beast: curating animals and ancestors at Çatalhöyük. World Archaeology 40: 373-89. 
PAYNE, S. 1985. Animal bones from Aşikli Hüyük. Anatolian Studies 35: 109-22.

PERKINS, D. 1969. Fauna of Çatal Hüyük: evidence for cattle domestication in Anatolia. Science 164: $177-9$.

Perkins, D.P. \& P. Daly. 1968. A hunters' village in Neolithic turkey. Scientific American 219: 96-106.

Peters, J., D. Helmer, A. von den Driesch \& M. SANA SEgUI. 1999. Early animal husbandry in the northern Levant. Paléorient 25: 27-47.

ROHRS, V.M. \& W. Herre. 1961. Zur Fruhentwicklung der Haustiere. Die Tierreste der neolithischen Sieldung Fikirtepe am Kleinasiatischen Gestade des Bosporus. Zeitschrift fur Tierzuchtung und Zuchtungs Biologie 75: 110-27.

RusSELl, N. \& L. MARTIN. 2005. The Çatalhöyük mammal remains, in I. Hodder (ed.) Inhabiting Catalhöyük: reports from the 1995-1999 seasons (McDonald Institute Monographs): 33-98. Cambridge: McDonald Institute for Archaeological Research/London: British Institute of Archaeology at Ankara.

Russell, N., L. Martin \& H. Buitenhuis. 2005. Cattle domestication at Çatalhöyük revisited. Current Anthropology 46: S101-08.

RÜtimeYer, L. 1862. Die Fauna der Pfablbauten der Schweiz. Zurich: Druck von Zilteher und Furrer.

Scheu, A., S. Hartz, U. Schmolcke, A. Tresset, J. Burger \& R. Bollongino. 2008. Ancient DNA provides no evidence for independent domestication of cattle in Mesolithic Rosenhof, Northern Germany. Journal of Archaeological Science 35: 1257-64.

SILVER, I.A. 1969. The aging of domestic animals, in D. Brothwell \& E. Higgs (ed.) Science in archaeology: 283-99. London: Thames \& Hudson.

STINER, M.C. 1994. Honor among thieves: a zooarchaeological study of Neandertal ecology. Princeton (NJ): Princeton University Press.
Thissen, L. 2002. Appendix I. CANeW ${ }^{14} \mathrm{C}$ databases and ${ }^{14} \mathrm{C}$ charts, Anatolia, 10,000-5,000 cal BC, in F. Gérard \& L. Thissen (ed.) The Neolithic of Central Anatolia: internal developments and external relations during the 9 th-6th millennia cal BC: 299-337. Istanbul: Ege Yayınları.

Vigne, J.-D., I. Carrere \& J. Guilaine. 2003. Unstable status of early domestic ungulates in the Near East: the example of Shillourokambos (Cyprus, IX-VIIIth millennia cal BC), in J. Guilaine \& A. Le Brun (ed.) Le Neolithique de Chypre. Actes du colloque international organise par le Department des Antiquites de Chypre et l'Ecole Française d'Athenes, Nicosie, 17-19 Mai 2001: 239-51. Athens: Ecole française d'Athenes.

Vigne, J.-D., G. Dollfus \& J. Peters. 1999. Les debuts de l'elevage au proche-orient: données nouvelles et reflexions. Paléorient 25: 5-8.

VON DEN Driesch, A. \& J. Peters. 1999. Vorläufiger

Bericht über die archäozoologischen Untersuchungen am Göbekli Tepe und am Gürcütepe bei Urfa, Türkei. Istanbuler Mitteilungen 49: 23-39.

ZEDER, M. 2001. A metrical analysis of a collection of modern goats (Capra hircus aegagrus and C. h. hircus) from Iran and Iraq: implications for the study of caprine domestication. Journal of Archaeological Science 28: 61-79.

- 2006. A critical assessment of markers of initial domestication in goats (Capra hircus), in M. Zeder, D.G. Bradley, E. Emschwiller \& B.D. Smith (ed.) Documenting domestication: new genetic and archaeological paradigms: 181-208. Berkeley (CA): University of California Press.

-2008 . Domestication and early agriculture in the Mediterranean Basin: origins, diffusion, and impact. Proceedings of the National Academy of Sciences 105: 11597-604. 